\title{
Covid-19 pandemic and the social determinants of health
}

\author{
Lauren Paremoer and colleagues call for action to create a fairer and more sustainable \\ post-covid world
}

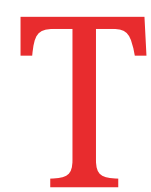

he covid-19 pandemic has exposed the longstanding structural drivers of health inequities, such as precarious and adverse working conditions, growing economic disparities, and anti-democratic political processes and institutions. These important determinants of health have interlinked with class, ethnicity, gender, education level, and other factors during covid-19 to exacerbate existing social vulnerabilities in society.

Numerous warnings of the dangers of inequity have emerged over the past decades. The Alma Ata declaration convincingly argued that "health for all" could be achieved only through a New International Economic Order and people's participation in decisions affecting their community's health. ${ }^{1}$ These principles were affirmed in the report of the Commission on the Social Determinants of Health ${ }^{2}$ and the 2008 World Health Report. ${ }^{3}$ The commission proposed "tackling the inequitable distribution of power, money, and resources" that drive systematic inequalities in health outcomes, and improving daily living conditions especially

\section{KEY MESSAGES}

- The covid-19 pandemic has affected groups that face discrimination and historical injustices hardest

- Poor and exploitative working and living conditions have increased health risks and enabled inequitable distribution of income

- Support systems that should have been geared to respond to this crisis proved inadequate

- Many (mainly authoritarian) governments have used the pandemic to further undermine civil and human rights and promote extractivism

- A post-covid world must ensure equity, social justice, solidarity, and a shift in the balance of power and resources to people living in poverty and otherwise marginalised for those in vulnerable circumstances. ${ }^{2}$ Historically, the social determinants of health agenda has been influential in highlighting and reducing inequities, ${ }^{45}$ and in relation to covid-19, academics and activists have called for a social determinants of health approach. ${ }^{67}$

From a social determinants of health perspective, global economic trends create enduring health hazards. These trends include the ballooning debt burden of low and middle income countries (LMICs), interpretations of the Trade-Related Intellectual Property Rights (TRIPs) agreement that undermine equitable access to medical technologies, and the pressure from the International Monetary Fund (IMF) on borrowers to implement austerity policies. These processes entrench the commercialisation of healthcare and constrain implementation of policies to reduce inequalities between and within countries. Additionally, the marginalisation of certain groups because of ethnicity, race, caste, migrant status, gender, class, or nature and conditions of work, for example, continues to undermine health.

Understanding what a post-covid world could look like necessitates an examination of key structural determinants that have contributed to the disproportionate effects of the covid-19 pandemic on marginalised and other groups, beyond the proximate drivers of the current crisis. Interventions to tackle systematically reproduced conditions of vulnerability would contribute towards a fairer and more sustainable world.

\section{Precarious work and adverse working conditions}

The covid-19 pandemic has highlighted that precarious work and exploitative and adverse working conditions intersect with multiple factors, including ethnicity, migrant status, class, and gender, to influence which population groups are most exposed to covid-19 infection. People in precarious forms of work have limited access to sick leave and healthcare services and their often low wages mean they cannot afford sufficient quality food, water and sanitation, and housing. They may also be hesitant to quarantine when they have covid-19 because they cannot afford to lose income and are unable to work from home. For example, major covid-19 outbreaks have occurred among meat workers globally. ${ }^{8}$ Working conditions in slaughterhouses are hazardous to health even without a pandemic, ${ }^{9}$ and covid-19 intensifies existing health risks. The physical configuration of slaughterhouses and communal housing and transport make social distancing near impossible. ${ }^{8}$ Some workers' immigration status makes them reluctant to join unions or challenge exploitative practices. $^{1011}$

In the US, people of colour make up $60 \%$ of warehouse and delivery workers and $74 \%$ of cleaning services workers. ${ }^{12}$ Partly as a result of this, ethnic minorities have been over-represented among covid-19 cases and deaths. ${ }^{13}$ A similar pattern has been seen in the UK, where the death rate from covid-19 is twice as high in black communities as in white communities. ${ }^{14}$ The more severe effect of covid-19 among people in precarious work is starkly illustrated in India, where lockdown caused migrant workers to lose their income and forced their return to home villages. One estimate suggests at least 971 deaths occurred among migrant workers and their families because of starvation, financial distress, injury, suicide, police brutality, and lack of access to medical care. ${ }^{15}$

Globally, women constitute $70 \%$ of those employed in health and social work. They are often engaged in lower status and poorly paid frontline worker positions and are at a greater risk of covid-19 because of their working conditions, especially in LMICs. ${ }^{16}$ For example, community health workers have undertaken covid19 surveillance, contact tracing, and monitoring quarantine and isolation, along with their regular tasks. ${ }^{17-19}$ Their work subsidises the public health system ${ }^{16}$ yet they are paid irregularly and inadequately, and often do not have adequate personal protective equipment. ${ }^{17-19}$ 
Nearly $40 \%$ of employed women worldwide work in sectors that were hit the hardest during the pandemic, leading to a loss or reduction of their incomes. ${ }^{1620}$ These include the informal sector, arts, entertainment, and domestic services. The International Labour Organisation estimates that as of 4 June 2020, 55 million or $72.3 \%$ of domestic workers were at risk of losing their jobs, of whom $67.3 \%$ were migrant workers and therefore at higher risk. ${ }^{16}$ From April 2019 to April 2020 women's employment fell by more than $16 \%$ even in Canada, Colombia, and the United States. Women are also estimated to be doing three quarters of the unpaid care work that has resulted from the closure of schools and childcare services during covid-19 and the increased care needs among older people. ${ }^{21}$

\section{Growing economic inequality and inadequate social protections}

The pandemic continues to widen income and wealth inequalities worldwide. The world's richest five billionaires enjoyed a 59\% increase in their combined wealth between March and September $2020^{22}$ at a time of higher global levels of unemployment, poverty, and debt. ${ }^{16}$ Around 435 million women and girls will be living on less than $\$ 1.90$ ( $€ 1.40 ; € 1.60)$ a day in 2021 , with 47 million in poverty as a result of covid-19. ${ }^{20}$ These growing economic inequalities are underpinned by weak regulatory control in financial and commercial markets, illicit financial flows, regressive taxation policies, and the increasing influence of transnational corporations in shaping national economies.

These increases in private wealth have corresponded to decreases in social wage (the goods, services, and payments that the state provides to all residents as a basic right). Combined with the commodification of food, land, seeds, and essential services, austerity policies that have reduced social protection measures have had a devastating effect on vulnerable groups and, during the pandemic, increasingly on the middle class. Social protection measures introduced during the pandemic, such as tax relief, cash transfers, unemployment benefits, and food and nutrition assistance, have mostly been inadequate as they have excluded or been inaccessible to those who need them the most, such as informal workers, migrants, young people, and displaced and indigenous populations. ${ }^{23}$ An $82 \%$ increase in hunger levels is predicted as a result of the pandemic, ${ }^{24}$ and the number of people facing acute food insecurity is expected to double, especially in countries affected by conflict, climate change, and economic crisis. ${ }^{21}$

The pandemic is also being exploited to intensify extractivist approaches to economic development. For example, in India covid-19 was used an excuse to reduce time for public consultation to push through weak environmental protection laws, ${ }^{25}$ and in the US the extractive industry is exploiting the pandemic by lobbying the government to suspend fuel efficiency standards and environmental laws. ${ }^{26}$

\section{Restrictive measures and anti-democratic political processes}

Control measures to contain the pandemic have disproportionately affected women and girls. Restrictions on freedom of movement have severely disrupted sexual and reproductive health services ${ }^{27}$ and could lead to an estimated seven million unintended pregnancies and thousands of deaths from unsafe abortions and complicated births globally. ${ }^{27}$ Lockdowns have also led to a worldwide increase in domestic and sexual violence, especially affecting women from indigenous, migrant, or refugee backgrounds, women with disabilities, and those living in conflict settings. ${ }^{28}$

Some governments have used covid-19 to introduce anti-democratic measures such as closing down courts, increasing surveillance, and passing emergency laws that are repressive. ${ }^{29}$ The UN special rapporteur on freedom of expression has raised concerns about the introduction of measures in Belarus, Cambodia, China, Iran, Egypt, India, Myanmar, and Turkey that restrict the free flow of information related to the pandemic and punish those distributing it. ${ }^{30}$ Numerous governments have also introduced surveillance measures (mostly digital) to track covid-19 transmission that in future could be used to monitor other activities, including political dissent. $^{31}$

While governments have used public health to justify restrictive regulations, they have not introduced regulatory measures on the private health sector that could increase access to covid-19 treatments, vaccines, medical technologies, and healthcare facilities. Such measures include prices regulation, prioritisation of production of covid related treatments, and the introduction of progressive solidarity taxes. The pandemic has brought to the fore the negative consequences of fragile and commercialised or profit driven health systems, especially for vulnerable groups already experiencing inequitable access to healthcare. ${ }^{32} 33$ For example, in Australia, by the end of July 2020 there were five deaths in public care homes for older people compared with 900 deaths in privatised homes. ${ }^{34}$

\section{Building a fairer post-covid 19 world}

Covid-19 has crystallised the need to address the "toxic combination of poor social policies, unfair economics, and bad politics [that are] responsible for much of health inequity." ${ }^{2}$ Countering this requires building solidarity to realise health for all. Since the Commission on Social Determinants for Health report, criticism of the unequal distribution of resources, power, and money has intensified. ${ }^{35}$ We suggest six measures (box 1) to enable a more just and sustainable world following the covid-19 pandemic.

Policies and interventions to tackle vulnerability in living and employment conditions are critical. These include social protection programmes to reduce poverty and safeguard livelihoods, including for informal workers. Decent work conditions will protect paid and unpaid workers from health threats, including covid-19. Governments should institutionalise policies that value the contribution of social reproduction work, and compensate people (mostly women) for the unpaid social reproduction work they do on a daily basis. The conditions of health and social care workers can be improved with the provision of formal contracts, decent wages, and non-exploitative working conditions. More broadly, the interdependence of reproductive and productive work should be recognised through institutionalising measures such as childcare and breastfeeding facilities at workplaces, paid parental leave, occupational health facilities, and subsidised healthy meals at work.

Governments could also reverse rapidly growing inequities by implementing progressive taxation, including wealth taxes. ${ }^{36}$ This would increase their ability to fund the public sector, including health and social services. Other measures include strengthening government administrative capacities to monitor and tax international financial flows. ${ }^{37}$ IMF requirements for austerity measures in countries given loans for covid-19 should also be lifted as they undermine national governments' policy autonomy and may lead to a lost development decade. ${ }^{38}$

Initiatives for progressive social change should also be implemented, including affirmative action in education, 


\section{Box 1: Measures to move towards a just and sustainable post-covid world}

- Design and implement policies to remove vulnerability in living and employment conditions-eg, public housing add ;? private rental controls; mandate against long term casual employment add ; ? introduce progressive labour laws, universal employment guarantee programmes, universal basic income programmes, social security pensions, childcare at workplace, parental leave, and school meals

- Implement progressive taxation and regulate illicit financial flows-eg, national taxation policies that ensure high income earners pay most tax and making corporations pay tax in the countries they operate

- Implement policies to address structural racism and discrimination against religious, ethnic, racial, and sexual minorities-eg, establish national anti-discrimination organisations, workplace unconscious bias and anti-racism training; pass laws to prohibit racist attacks and discrimination; and implement affirmative action laws and policies

- Strengthen public sector provision of healthcare and stop further healthcare privatisation and commercialisation-eg, increase health budgets to at least $5 \%$ of GDP, finance the public health system to provide services rather than outsource, increase resources to areas and communities that are currently underserved, regulate private providers

- Invest in human resources for health, including community health workers and those trained in public health infectious disease control-eg, implement fair wages for all health workers, reduce use of short term contracts, train and recruit health workers from the local area to ensure retention

- Democratise decision making about healthcare services and medical technologies at community, national, and global levels-eg, include the community (especially those most affected) and people's representatives in decision making structures, monitor and take action on possible conflicts of interest in health governance structures, implement laws supporting freedom of the press

employment, and political representation; laws against discrimination; and support for communities to build their capacities to organise against anti-democratic measures, inequalities, and racism. ${ }^{39}$ This includes the implementation of laws and policies to ensure access to healthcare services is based on medical need rather than on ability to pay or social status and that services are tailored to recipients' cultural, linguistic, and religious requirements.

Access to healthcare also remains hampered as the healthcare and pharmaceutical industries seek profits in a way that makes it unaffordable for many. Commercialisation is continuing under the guise of promoting universal health coverage, and in some countries, such as the UK, as a rationale for institutionalising an efficient response to covid-19. ${ }^{40}$ Governments should instead work towards institutionalising and financing universal coverage through progressive taxation schemes and provide primary healthcare and services to everyone as conceptualised in the Alma Ata declaration ${ }^{41}$ and by the Commission on Social Determinants of Health. Furthermore, the capacity and efficacy of the public sector as a provider of healthcare, especially to people from marginalised groups, should be strengthened, including by recruiting and training adequate numbers of health workers and providing fair wages, social protection, and a conducive working environment.

Defending the principle that people have a right to participate in decisions about their health and in processes affecting it, including economic processes, is central to building solidarity for health for all. This means resisting global and national health governance processes that privilege organisations not subject to democratic oversight. For example, the privatisation of global health governance gives stakeholders with huge financial resources-such as philanthropic foundations, commercial consulting firms, and drug companies who are beholden to shareholders or governing boards disproportionate power to define health priorities and solutions. Democratically elected governments are best placed to demand and support action on the social and economic determinants of health to prevent and manage future pandemics. ${ }^{42}$

The erosion of national autonomy is also echoed in international agreements such as TRIPS, which the most powerful states in the World Trade Organisation are interpreting in a manner that undermines equitable access to covid-19 medical technologies. ${ }^{43}$ If global governance for health is to be meaningful, international trade agreements must promote the public good rather than defend private interests. The pandemic also reiterates the urgent need for the binding instrument on transnational corporations and human rights that is currently being negotiated within the United Nations.

In conclusion, the covid-19 pandemic has exposed the health effects of longstanding social inequities and that vulnerability to disease is shaped by labour market structures, lack of social protection, and anti-democratic processes. The effect of these structural inequities on populations is mediated by intersecting social dimensions, including occupation, class, ethnicity, race, citizenship status, and gender. The pandemic has highlighted the unequal distribution of power and resources, and people are also using this moment to challenge these inequalities anew. Governments and the international community must take responsibility for rebuilding social protection and solidarity to protect populations from future health challenges, while civil society and social movements also have a role in holding decision makers to account.

\section{We thank Deepika Joshi for her research assistance.}

Contributors and sources LP's research focuses on global governance for health, with a focus on gender and the politics of decommodifying healthcare and medicines. SN works in Chhattisgarh state of India on issues of health rights and has undertaken research on health equity and access, public policy and programmes for health and nutrition, and health privatisation, with a focus on gender and vulnerable communities. HS's research focuses on health system policies, health equity, and governance for health. FB is the Matthew Flinders distinguished professor of public health at the Southgate Institute for Health, Society and Equity and co-chair of the Steering Council of the People's Health Movement. LP led the writing of the article and is the guarantor. SN, HS, FB contributed to the conceptualisation and commented on drafts and approved the final version.

Competing interests All authors have read and understood BMJ policy on declaration of interests and have no relevant interests to declare.

Provenance and peer review: Commissioned; externally peer reviewed.

This article is part of a collection launched at the Prince Mahidol Awards Conference (PMAC) in January 2021. Funding for the articles, including open access fees, was provided by PMAC. The BM/ commissioned, peer reviewed, edited, and made the decision to publish these articles. David Harper and an expert panel that included PMAC advised on commissioning for the collection. Rachael Hinton and Kamran Abbasi were the lead editors for The BMJ.

Lauren Paremoer, senior lecturer ${ }^{1}$

Sulakshana Nandi, co-chair of global steering council $^{2,3}$

Hani Serag, director of programmes ${ }^{4}$

Fran Baum, director ${ }^{2,5}$ 
${ }^{1}$ Political Studies, University of Cape Town, Cape Town, South Africa

'People's Health Movement, Delhi, India

${ }^{3}$ Public Health Resource Network Chhattisgarh, Raipur, India

${ }^{4}$ Center for Global and Community Health, University of Texas Medical Branch at Galveston, Galveston, Texas, USA

${ }^{5}$ Southgate Institute for Health, Society and Equity, Flinders University, Adelaide, Australia

Correspondence to: S Nandi

sulakshana@phmovement.org

\section{Check for updates}

This is an Open Access article distributed in accordance with the Creative Commons Attribution Non Commercial (CC BY-NC 4.0) license, which permits others to distribute, remix, adapt, build upon this work non-commercially, and license their derivative works on different terms, provided the original work is properly cited and the use is non-commercial. See: http://creativecommons.org/ licenses/by-nc/4.0/.

\section{(c) $\underset{\text { (1) } 8 \text { (8) }}{\text { OPC }}$ OPEN ACCESS}

1 World Health Organization. Declaration of Alma-Ata: international conference on primary health care, Alma-Ata, USSR, 6-12 September 1978. WHO, 1978. https://www.who.int/publications/almaata_ declaration_en.pdf.

2 WHO Commission on Social Determinants of Health. Closing the gap in a generation. World Health Organization, 2008.

3 World Health Organization. Primary health care (now more than ever). In: World Health Report. WHO, 2008.

4 African Union, African health strategy 2016 - 2030. African Union, 2015

5 Pan American Health Organization. Commission on equity and health inequalities presents 12 recommendations to reduce inequities in the Americas. 2018. https://www.paho.org/hq/index. php?option=com_content\&view=article\&id $=1468$ 7:commission-on-equity-and-health-inequalitiespresents-12-recommendations-to-reduce-inequitiesin-the-americas\&ltemid=135\&lang=en .

6 Buse K, Nilo A, Kim J, Heywood M, Acaba J. COVID-19 combination prevention requires attention to structural drivers. Lancet 2020;396:466. doi:10.1016/S0140-6736(20)31723-2

7 Prasad V, Sri BS, Gaitonde R. Bridging a false dichotomy in the COVID-19 response: a public health approach to the 'lockdown' debate. $B M$ Glob Health 2020;5:e002909. doi:10.1136/ bmigh-2020-002909

8 Kinniburgh C. Covid-19: How the meat industry became a global health liability. 2020. https://www. france24.com/en/20200524-covid-19-how-themeat-industry-became-a-global-health-liability.

9 Pachirat T. Every twelve seconds: industrialized slaughter and the politics of sight. Human Rights Watch 29 May 2020. https://www.hrw.org/ news/2020/05/29/germany-protect-meatpackingworkers-better

10 Meng G, Williamson H. Germany to protect meatpacking workers better: US should emulate Germany's workers-first response. Human Rights Watch, 2020.https://www.hrw.org/ news/2020/05/29/germany-protect-meatpackingworkers-better.
11 Boseley M. Cedar Meats cluster: why abattoir workers are on the coronavirus frontline. Guardian2020 May 8. https://www.theguardian.com/australianews/2020/may/09/cedar-meats-cluster-whyabattoir-workers-are-on-the-coronavirus-frontline

12 National Institute for Health Care Management Foundation. Population health-Covid-19's differential impact on workers. 2020 .https://www. nihcm.org/categories/publications/covid-19-sdisproportionate-impact-on-workers.

13 Wood D. As pandemic deaths add up, racial disparities persist - and in some cases worsen. 2020. https://www.npr.org/sections/healthshots/2020/09/23/914427907/as-pandemic deaths-add-up-racial-disparities-persist-and-insome-cases-worsen

14 Office for National Statistics. Updating ethnic contrasts in deaths involving the coronavirus (COVID-19), England and Wales: deaths occurring 2 March to 28 July 2020. 2020. https://www.ons.gov. uk/peoplepopulationandcommunity/ birthsdeathsandmarriages/deaths/articles/ updatingethniccontrastsindeathsinvolvingthe coronaviruscovid19englandandwales/ deathsoccurring2marchto28july2020.

15 Stranded Workers Action Network. No data, no problem: centre in denial about migrant worker deaths and distress. 16 Sep 2020 .https://thewire. in/rights/migrant-workers-no-data-centre-covid-19lockdown-deaths-distress-swan.

16 International Labour Organization. COVID-19 and the world of work. ILO Monitor 2020 June. https:// www.ilo.org/wcmsp5/groups/public/@dgreports/@ dcomm/documents/briefingnote/wcms_749399. pdf.

17 Lotta G, Wenham C, Nunes J, Pimenta DN. Community health workers reveal COVID-19 disaster in Brazil. Lancet 2020;396:365-6. doi:10.1016/S01406736(20)31521-X

18 Nepomnyashchiy L, Dahn B, Saykpah R, Raghavan M. COVID-19: Africa needs unprecedented attention to strengthen community health systems. Lancet 2020;396:150-2. doi:10.1016/S01406736(20)31532-4

19 Rao B, Tewari S. Distress among health workers in covid-19 fight. 9 Jun 2020. https://www.article-14. com/post/anger-distress-among-india-s-frontlineworkers-in-fight-against-covid-19.

20 Azcona G, Bhatt A, Encarnacion J, et al. From insights to action: Gender equality in the wake of COVID-19. 2020 .https://www.unwomen.org/en/digital-library/ publications/2020/09/gender-equality-in-the-wakeof-covid-19.

21 United Nations Development Programme. Putting the UN Framework for socio-economic response to covid-19 into action. Insights 2020. 2020. https:// reliefweb.int/report/world/brief-2-putting-unframework-socio-economic-response-covid-19action-insights-june-2020

22 Anderson S, Wakamo B. Inequality and COVID-19 in 13 charts. 25 Sep 2020. https://ips-dc.org/ inequality-and-covid-19-in-13-charts/.

23 United Nations Human Rights Special Procedures - Special Rapporteurs - Independent Experts \& Working Groups. Special rapporteur on extreme poverty and human rights. Looking back to look ahead: a rights-based approach to social protection in the post-COVID-19 economic recovery. 2020 https://www.ohchr.org/Documents/Issues/Poverty/ covid19.pdf.

24 United Nation World Food Programme (WFP). COVID-19 will double number of people facing food crises unless swift action is taken. 21 Apr 2020. https://www.wfp.org/news/covid-19-will-doublenumber-people-facing-food-crises-unless-swiftaction-taken.

25 Deshmane A. Overruled his own officials, cut short window for consultation to push controversial environmental law. Huffington Post2020. https://www.huffingtonpost.in/ entry/prakash-javadekar-news-environmentministry-narendra-modi-government in_5ef496d1c5b615e5cd39d160

26 Center for International Environmental Law. Pandemic crisis, systemic decline: why exploiting the covid-19 crisis will not save the oil, gas, and plastic industries. 2020. https://www.ciel.org/reports/ pandemic-crisis-systemic-decline/.

27 Cousins S. COVID-19 has "devastating" effect on women and girls. Lancet 2020:396:301-2. doi:10.1016/S0140-6736(20)31679-2

28 United Nations. Particular challenges of women and girls in the context of COVID-19. Global humanitarian response plan or Covid-19, May update. 2020. https://unric.org/it/wp-content/uploads/ sites/3/2020/05/GHRP-COVID19_MayUpdatePart-2.pdf.

29 Erlanger S. Poland and Hungary use coronavirus to punish opposition. New York Times 2020 Apr 22. https://www.nytimes.com/2020/03/30/ world/europe/coronavirus-governments-power. html.

30 United Nations Human Rights-Office of the High Commissioner. COVID-19 pandemic exposes repression of free expression and right to information worldwide, UN expert says. 10 Jul 2020. https://www.ohchr. org/EN/NewsEvents/Pages/DisplayNews. aspx?News|D=26075\&LangID=E.

31 Amnesty International. COVID-19, surveillance and the threat to your rights. 2020. https://www. amnesty.org/en/latest/news/2020/04/covid-19. surveillance-threat-to-your-rights/.

32 Moore JT, Ricaldi JN, Rose CE, et al, COVID-19 State, Tribal, Local, and Territorial Response Team. Disparities in incidence of covid-19 among underrepresented racial/ethnic groups in counties identified as hotspots during June 5-18, $2020-22$ States, February-June 2020. MMWR Morb Mortal Wkly Rep 2020;69:1122-6. doi:10.15585/mmwr. mm6933e1

33 Lassale C, Gaye B, Hamer M, Gale CR, Batty GD. Ethnic disparities in hospitalisation for COVID-19 in England: The role of socioeconomic factors, mental health, and inflammatory and pro-inflammatory factors in a community-based cohort study. Brain Behavlmmun 2020;88:44-9. doi:10.1016/j. bbi.2020.05.074

34 Visontay E, Butler B, Henriques L. Chaos at Victoria's Epping Gardens: how privatised aged care has failed during the coronavirus pandemic. Guardian 2000 Jul 30. https://www.theguardian.com/world/2020/ jul/31/chaos-at-victorias-epping-gardens-howprivatised-aged-care-has-failed-during-thecoronavirus-pandemic

35 Oxfam. Even it up: time to end extreme inequality. 2020 .https://oxfamilibrary.openrepository.com/ oxfam/bitstream/10546/333012/43/cr-even-it-upextreme-inequality-291014-en.pdf

36 Mccoy D, Chigudu S, Tillmann T. Framing the tax and health nexus: a neglected aspect of public health concern. Health Econ Policy Law 2017;12:179-94. doi:10.1017/ S174413311600044X

37 UN Economic Commission for Africa. Illicit financial flow: report of the high level panel on illicit financial flows from Africa. 2011. http://hdl.handle. net/10855/22695

38 UNCTAD. COVID-19: UNCTAD warns of 'lost decade' if countries adopt austerity. 21 Sep 2020 .https:// unctad.org/news/covid-19-unctad-warns-lostdecade-if-countries-adopt-austerity.

39 Williams DR, Lawrence JA, Davis BA. Racism and health: evidence and needed research. Annu Rev Public Health 2019:40:105-25. doi:10.1146 annurev-publhealth-040218-043750 
40 McCoy D. Countries from Germany to Vietnam got test and trace right, so why didn't England? Guardian 2020 Jun16. https://www.theguardian.com/

commentisfree/2020/jun/16/germany-vietnam-testtrace-england-coronavirus.

41 Sanders D, Nandi S, Labonté R, Vance C, Van Damme W. From primary health care to universal health coverage-one step forward and two steps back.
Lancet 2019:394:619-21. doi:10.1016/S0140 6736(19)31831-8

42 Baum F, Narayan R, Sanders D, Patel V, Quizhpe

A. Social vaccines to resist and change

unhealthy social and economic structures: a

useful metaphor for health promotion. Health

Promot Int 2009;24:428-33. doi:10.1093/

heapro/dap026
43 Kanth R. Proposal for TRIPS waiver secures strong support from South. 19 Oct 2020. https://twn.my/ title2/wto.info/2020/ti201020.htm.

Cite this as: $B M / 2021 ; 372: n 129$

http://dx.doi.org/10.1136/bmj.n129 